Plumpton, H. M., S. G. Gilliland, and B. E. Ross. 2020. Movement ecology and habitat use differences in Black Scoters wintering along the Atlantic coast. Avian Conservation and Ecology 15(2):6. https://doi.org/10.5751/ACE-01654-150206

Copyright (C) 2020 by the author(s). Published here under license by the Resilience Alliance.

Research Paper

\title{
Movement ecology and habitat use differences in Black Scoters wintering along the Atlantic coast
}

\author{
Hannah M. Plumpton ${ }^{1}$, Scott G. Gilliland ${ }^{2}$ and Beth E. Ross ${ }^{3,4}$ \\ ${ }^{1}$ Department of Forestry and Environmental Conservation, Clemson University, ${ }^{2}$ Canadian Wildlife Service, Environment and \\ Climate Change Canada, ${ }^{3}$ U.S. Geological Survey, South Carolina Cooperative Fish and Wildlife Research Unit, ${ }^{4}$ Clemson \\ University, Department of Forestry and Environmental Conservation
}

\begin{abstract}
For migratory species such as Black Scoters (Melanitta americana) whose range encompasses a variety of habitats, it is especially important to obtain habitat use information across the species' range to better understand anthropogenic threats, e.g., marine development and climate change. The objective of our study was to investigate the winter movement patterns and habitat use of Black Scoters in the Atlantic Ocean by quantifying the following key movement indices: number of wintering sites, arrival and departure dates to and from the wintering grounds, days at a wintering site, area of a wintering site, distance between wintering sites, and differences in habitat features of wintering sites. We also tested if winter movement patterns varied by sex or along a latitudinal gradient. To quantify winter movement patterns of Black Scoters, we used satellite telemetry data from 2009 to 2012 (n = 29 tagged females and 15 males for a total of 66 winter seasons, 38 female winter seasons, 28 male winter seasons). Our results indicated that the average wintering site area and distance between wintering sites varied with latitude. Wintering sites located at southern latitudes were larger and further apart than wintering sites located at more northern latitudes. Additionally, wintering sites varied in bathymetry, distance to shore, and the slope of the ocean floor at different latitudes; northern wintering sites were in deeper waters, closer to shore, and on steeper slopes than southern wintering sites. Our results suggest that habitat use may differ by latitude, indicating that habitats used in northern locations may not be representative of habitats used in more southern wintering areas. Understanding variation of habitat use along a latitudinal gradient will enable managers to focus sampling effort for Black Scoter abundance and distribution along the Atlantic coast and provide insight on the wintering ecology and movement of Black Scoters.
\end{abstract}

\section{Écologie des déplacements et différences d'utilisation des habitats chez les Macreuses à bec jaune hivernant le long de la côte atlantique}

RÉSUMÉ. Pour les espèces migratrices dont l'aire de répartition englobe une variété d'habitats telles que la Macreuse à bec jaune (Melanitta americana), il est primordial d'obtenir des informations sur l'utilisation des habitats dans l'ensemble de l'aire de répartition de l'espèce afin de mieux comprendre les menaces d'origine anthropique, dont l'exploitation des ressources maritimes et le changement climatique. L'objectif de notre étude était d'examiner les patrons de déplacements hivernaux et l'utilisation des habitats de la Macreuse à bec jaune dans l'océan Atlantique, en quantifiant les principaux indices de déplacement suivants : nombre de sites d'hivernage, dates d'arrivée et de départ des sites d'hivernage, jours passés sur un site d'hivernage, superficie d'un site d'hivernage, distance entre les sites d'hivernage et différences dans les caractéristiques d'habitats aux sites d'hivernage. Nous avons également vérifié si les patrons de déplacements hivernaux variaient selon le sexe ou un gradient latitudinal. Pour quantifier les patrons de déplacements hivernaux de la Macreuse à bec jaune, nous avons utilisé des données de télémétrie par satellite de 2009 à 2012 ( $\mathrm{n}=29$ femelles et 15 mâles pour un total de 66 hivers, soit 38 hivers pour les femelles et 28 hivers pour les mâles). Nos résultats ont indiqué que la superficie moyenne des sites d'hivernage et la distance entre les sites d'hivernage variaient en fonction de la latitude. Les sites d'hivernage situés aux latitudes sud étaient plus grands et plus éloignés les uns des autres que les sites d'hivernage situés aux latitudes nord. En outre, les sites d'hivernage variaient en termes de bathymétrie, de distance par rapport au rivage et de pente du fond océanique à différentes latitudes; les sites d'hivernage situés au nord se trouvaient dans des eaux plus profondes, plus près du rivage et sur des pentes plus raides que les sites d'hivernage situés au sud. Nos résultats indiquent que l'utilisation des habitats peut varier en fonction de la latitude, nous portant à croire que les habitats utilisés dans les zones d'hivernage septentrionales ne sont peut-être pas représentatifs des habitats utilisés dans les zones plus méridionales. La compréhension des différences dans l'utilisation des habitats le long d'un gradient latitudinal permettra aux gestionnaires de concentrer leurs efforts de suivi de l'abondance et de la répartition de la Macreuse à bec jaune le long de la côte atlantique et fournit un aperçu de l'écologie hivernale et des déplacements de la Macreuse à bec jaune.

Key Words: Black Scoter; geographic variation; Melanitta americana; movement; wintering ecology

Correspondent author: Beth E. Ross, U.S. Geological Survey, South Carolina Cooperative Fish and Wildlife Research Unit, Clemson University, Clemson, SC, USA 29634, bross5@clemson.edu 


\section{INTRODUCTION}

For migratory species, spatial variation in habitat responses within portions of the annual cycle may make it inappropriate to presume a species responds similarly to habitat throughout their migratory range, e.g., a similar response to habitat throughout their breeding range (Parody and Parker 2002, Rannap et al. 2012). Understanding spatial variation in responses to environmental conditions within portions of the migratory cycle of a species can better inform conservation and management (Grzybowski et al. 1994, Whittingham et al. 2006).

Sea ducks (tribe: Mergini) comprise a group of waterfowl of conservation and management importance that provide a unique opportunity to study varying responses to environmental conditions across different habitats throughout the nonbreeding portion of their migration cycle. Most North American sea duck research conducted during the nonbreeding season focuses on portions of the population that winter in northern locations (off the coast of Alaska and British Columbia in the Pacific Ocean and off the coast of eastern Canada and New England in the Atlantic Ocean; Bowman et al. 2015). Research on the southern wintering populations, those that winter along the Pacific coast of the continental United States and the Mid-Atlantic and southeastern coast of the United States, is limited. Tidal regimes, sediments, food resources, and temperature regimes shift along different latitudes (Spalding et al. 2007, Boyd et al. 2015), which could influence the movement and distribution of sea ducks (Nilsson 1972, Stott and Olson 1973, Kirk et al. 2008, Schummer et al. 2008).

Sea ducks on their wintering range respond to a variety of factors including local environmental conditions (Loring et al. 2014, Beuth et al. 2017), food availability (Guillemette et al. 1993, Lewis et al. 2008), predation risk, site fidelity (Greenwood 1980), and human activity, such as hunting (Madsen and Fox 1995). Sea duck movements and site use in relation to environmental factors are vastly unknown and understudied along the Atlantic coast of the United States (Kaplan 2011, Jodice et al. 2013, Boyd et al. 2015), but variation in resources may have carry-over effects throughout their annual cycle (Alisauskas and Ankney 1992, Scott 1998, Martin and Wiebe 2004).

Carry-over effects can strongly impact both ecological and evolutionary processes in birds (Ebbinge and Spaans 1995, Norris et al. 2004, Sorensen et al. 2009). Poor quality habitat and a scarcity of resources during the wintering period and spring migration can decrease chances of survival and lower body condition for the subsequent phases of the annual cycle, e.g., carry-over effects (Gunnarsson et al. 2006, Studds and Marra 2007, Rushing et al. 2017). These carry-over effects likely originate from variation in resource abundance on the wintering grounds. The quality and quantity of habitats and resources during the nonbreeding season may be important limiting factors for waterfowl (Lack 1966, Fretwell 1972, Sedinger and Alisauskas 2014, Alisauskas and Devink 2015), and can have detrimental effects on population dynamics (Alisauskas and Ankney 1992, Scott 1998, Martin and Wiebe 2004). Poor winter habitat conditions have been associated with large mortality events (Camphuysen et al. 2002), decreased reproductive success (Nichols et al. 1983, Oosterhuis and Dijk 2002, Guillemain et al. 2008), and decreased population growth rate (Petersen and Douglas 2004, Sorensen et al. 2009, Wilson et al. 2011).
Information on winter habitat use for sea ducks is needed to identify areas of good quality habitat, but that information is limited (Sea Duck Joint Venture 2015). Additionally, sea ducks encounter potential impacts from a variety of anthropogenic activities, i.e., offshore energy, sand mining, fisheries bycatch, aquaculture, eutrophication, and disturbance/displacement, but it is unknown how these activities might affect their winter distribution (Silverman et al. 2013), or if these effects vary between northern and southern wintering sites. Because of carryover effects, conservation and management of habitat for sea ducks during winter could affect populations throughout the entire life cycle.

A sea duck species of high conservation concern is the Black Scoter (Melanitta americana; Sea Duck Joint Venture Management Board 2014). The Black Scoter is listed on the International Union for Conservation of Nature and Natural Resources (IUCN) Red List of Threatened Species as "Near Threatened" (BirdLife International 2013). Black Scoters are long-lived sea ducks that breed in Alaska and Canada and winter off the coastlines of the United States and Canada (Bordage and Savard 2011, Sea Duck Joint Venture 2015). Although there is considerable information known about the Pacific population of Black Scoters (Schamber et al. 2010), there is very little information known about the Atlantic population (Bordage and Savard 2011, Boyd et al. 2015, Sea Duck Joint Venture 2015). As anthropogenic activity along the Atlantic coast has risen, there has been an increased effort to learn more about the winter habitat use and movement patterns of Black Scoters along the Atlantic coast (Bordage and Savard 2011, Loring et al. 2014, Bowman et al. 2015). Previous work examined the habitat use of Black Scoters in southern New England and the potential overlap with prospective offshore wind energy sites (Loring et al. 2014), but little is known about habitat use throughout the entire wintering range. New England composes a small portion of the wintering range of Black Scoter, and the identification of environmental conditions on the wintering grounds, i.e., Atlantic Ocean along the United States, may vary among wintering sites, i.e., core use areas, and marine ecoregions within the Atlantic. Marine ecoregions are regions of relatively similar benthic and shelf pelagic (neritic) species composition and are clearly distinct from adjacent ecoregions as a result of temperature regimes, currents, bathymetry, and sediments (Spalding et al. 2007). Because Atlantic Black Scoter primarily winter throughout two marine ecoregions (the more northern Virginian and more southern Carolinian; Fig. 1), it is likely that habitat use varies by ecoregion and latitude.

To better understand wintering site use and movement patterns of Black Scoters during the nonbreeding season, we analyzed winter locations of Black Scoters along the Atlantic Coast, acquired via satellite telemetry, to (1) delineate arrival and departure dates to and from the wintering grounds; (2) identify the number of wintering sites used, area of each site, and duration of time spent at each site during the wintering period; (3) delineate the distance traveled between wintering sites; (4) quantify differences in migration timing and site use latitude; and (5) identify differences in habitat features for wintering sites by latitude. The information from this study will increase the knowledge on wintering ecology of Black Scoters and provide new insight into Black Scoter conservation and management. 
Fig. 1. Fixed kernel density map for Black Scoters (Melanitta americana) that were satellite tagged with a platform transmitting terminal (PTT) during wintering seasons of 2009 2013 along the Atlantic coast of the United States. Core use areas ( 0.5 isopleth) are identified in dark grey and the wintering range ( 0.95 isopleth) in light grey along with the marine ecoregions that are along the Atlantic Coast of the United States.

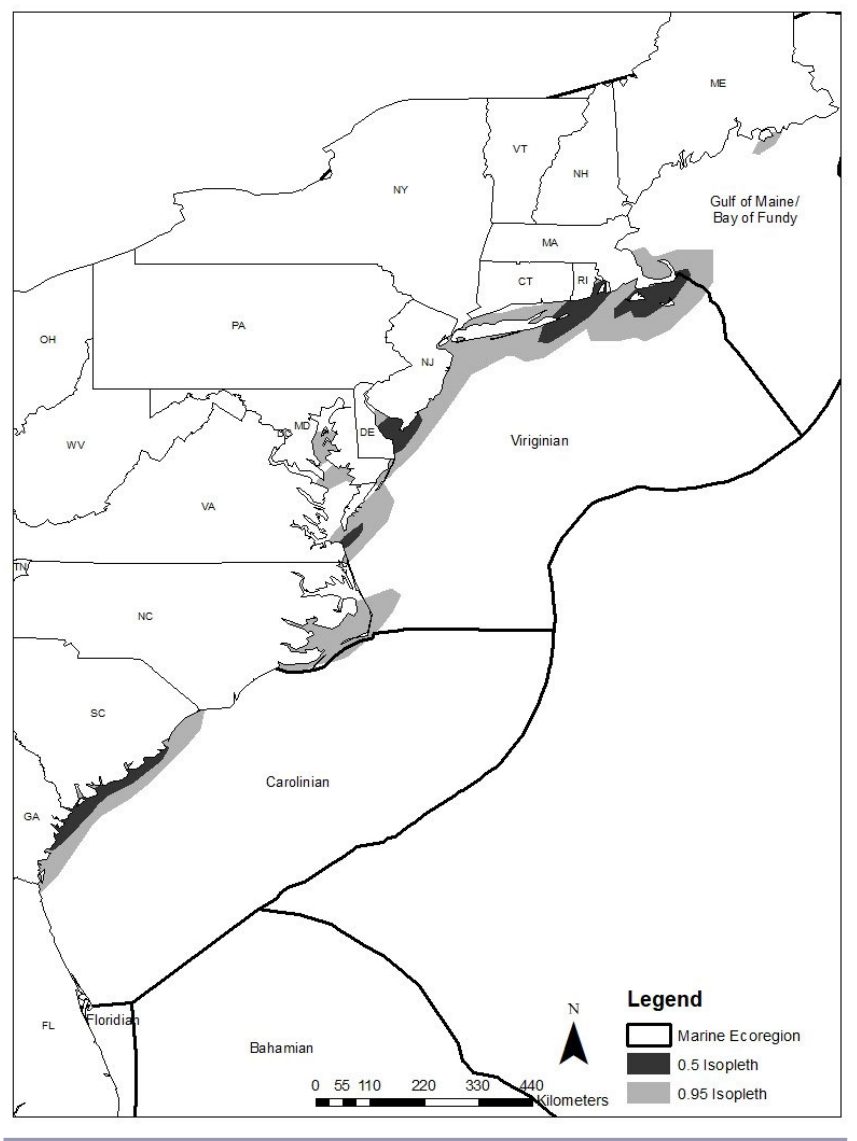

\section{METHODS}

Chaleur Bay, New Brunswick/Québec, Canada is a major spring stopover for migrating sea ducks, including Black Scoters (Sea Duck Joint Venture 2015). Floating mist nests were used to capture 19 adult female Black Scoters in May 2009 and 47 adult Black Scoters (19 females and 28 males) in May 2010 in Chaleur Bay as part of the Atlantic and Great Lakes Sea Duck Migration Study that focused on female locations throughout the annual cycle (S. Gilliland, personal communication). Each scoter was surgically implanted with a satellite transmitter (PTT) in the abdominal cavity following Korschgen et al. (1996). The PTTs weighed 38-50 grams ( $<4 \%$ of average body mass), had a percutaneous antenna, and had a battery life of $\geq 750$ hours. The duty-cycle of the transmitters in 2009 was 6 hours on and 72 hours off, which resulted in an average battery life of 438 days. The dutycycle of the transmitters in 2010 was 2 hours on and 72 hours off, which resulted in an average battery life of 803 days. The duty- cycles of the transmitters were set to capture a location at a range of times throughout the day and prevent any bias that might occur by using a particular period of time (Sea Duck Joint Venture 2015). We excluded location data collected within the first 12 weeks of deployment to remove acute effects of transmitter deployment (Esler et al. 2000), though sea ducks typically return to baseline movement patterns within five days of release (Lamb et al. 2020). Birds were not recaptured during the study. The telemetry data from the PTTs were collected via the Argos system of satellites, downloaded nightly and archived, and filtered with the Douglas Argos-Filter Algorithm (DAF) to remove redundant data and errant points (Douglas et al. 2012). More details about the capture methodology are described in Loring et al. (2014) as data from 23 of the 47 Black Scoters captured in 2010 were used in Loring et al. (2014) study.

Because of the different duty cycle used between years, we standardized the location data by removing any points that occurred later than two hours after the first point recorded for each duty cycle, resulting in both years having points in a twohour window. The DAF assigns a location class based on the quality (accuracy) of the location recorded. We retained points with location errors $<10 \mathrm{~km}$ (location classes L3, L2, and L1; Douglas et al. 2012). Preliminary examination of the data indicated that using the location error associated with these location classes would not greatly affect the delineation of wintering sites, because of the size of the wintering sites relative to the possible location error. We defined "winter" for each Black Scoter from the first location recorded south of the U.S.-Canada border $\left(44^{\circ} 50^{\prime} \mathrm{N}\right)$ to the last location recorded south of the U.S.Canada border. The data for each scoter were separated by year, with points occurring after 31 August and before 1 May of the following year, i.e., 1 September 2010-30 April 2011). We excluded any points that were farther west than the coast of Florida $\left(-81^{\circ}\right.$ $\left.50^{\prime} \mathrm{W}\right)$ and farther north than the U.S.-Canada border $\left(44^{\circ} 50^{\prime}\right.$ $\mathrm{N})$. The majority of Black Scoters molt along the western Hudson Bay and James Bay, Canada with a few molting along the Canadian coast before continuing their migration to the wintering grounds (Sea Duck Joint Venture 2015). We choose to exclude the Canadian coast because of a lack of comparable habitat data. We randomly selected one location per bird per day to minimize spatial bias when comparing between birds and years. An individual was included in the calculations if there were $\geq 30$ locations for a given winter season (Seaman et al. 1999).

\section{Wintering sites and arrival and departure dates}

For each bird, the date of arrival to and departure from the wintering grounds in the United States was specified as the earliest and latest date recorded at the individual's first and last wintering site, respectively. We define a "wintering site" as an area where a Black Scoter spent $\geq 7$ days along the Atlantic coast of the United States (Phillips et al. 2006). Black Scoters can have multiple wintering sites. The number of wintering sites that were used annually for each scoter was determined by applying a 50\% fixed kernel utilization distribution (UD), i.e., core habitat use, with the plug-in method for bandwidth selection using the "ks" package (Duong 2017) in Program R (version 3.4.0, R Development Core Team 2017). Each polygon created after applying a $50 \%$ fixed kernel UD was delineated as a "wintering site." The first wintering 
site birds arrived on once they reached the wintering grounds was the "first wintering site." If a bird then moved to another wintering site, we called this site the "second wintering site." A wintering site was used more than once if the scoter spent more than 14 days away from a wintering site and then returned to it; 14 consecutive days was deemed sufficient for a scoter to establish another wintering site before returning to the original wintering site. We defined the time spent at a wintering site as the "period at a wintering site." Because a wintering site could be used multiple times, the next time period at a wintering site was considered the "second period at a winter site," regardless of whether it was the previously used wintering site or a new wintering site.

\section{Wintering site area and distance between wintering sites}

We removed nonavailable habitat, i.e., land, from the 50\% home range area and calculated the area of each polygon using ArcMap 10.5.1 (ESRI 2011). The center of the polygons representing each wintering site was calculated by using the "Feature to Point" tool in ArcGIS. The distance traveled between the wintering sites was calculated by using the points representing the center of each wintering site and the "Point Distance" tool in ArcGIS (Fig. 2). We calculated the average area of the wintering sites by averaging the size of all wintering sites for each bird annually. We calculated the average distance between wintering sites by averaging all the distances between wintering sites for each bird annually.

Fig. 2. Fifty percent fixed kernel density map for one Black Scoter (Melanitta americana; as an example) that was satellite tagged with a Platform Transmitting Terminal (PTT) during a wintering season along the Atlantic coast of the United States during the winter of 2010-2011. The map identifies the number of wintering sites used during the wintering period, the area of each wintering site $\left(\mathrm{km}^{2}\right)$, and the distance between the wintering sites $(\mathrm{km})$.

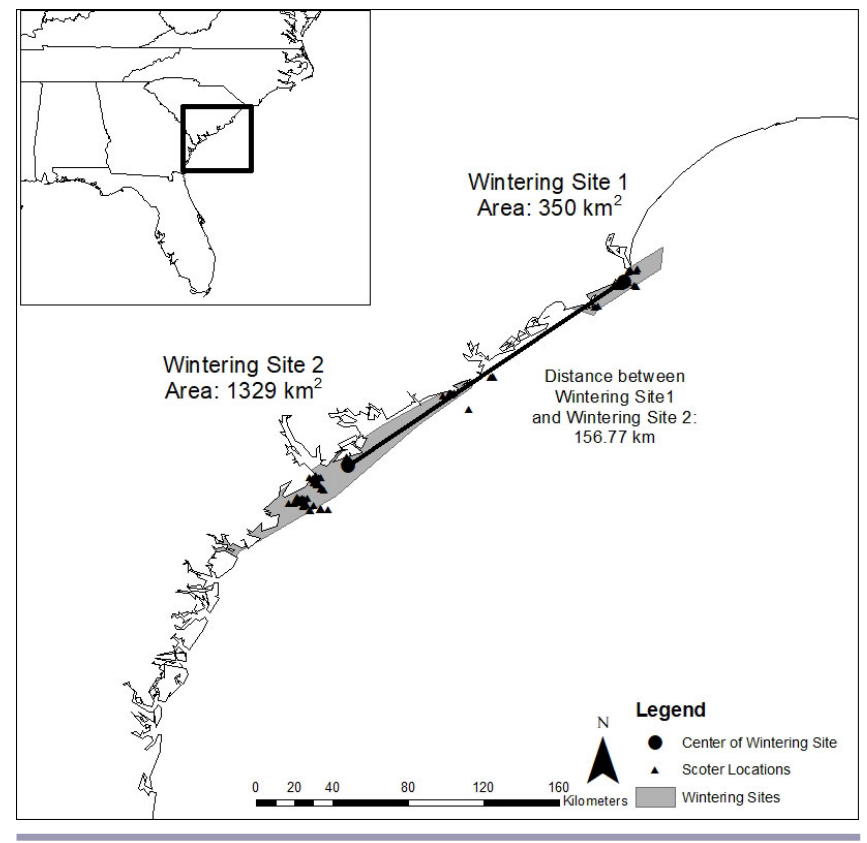

\section{Statistical analyses}

We used generalized linear mixed models (GLMM) in R (package lme4; Bates et al. 2015) with year and individual scoter as random effects to examine how the predictor variables of sex, mean latitude of birds, and standard deviation of latitude of birds affected the response variables of (1) arrival date to the wintering grounds for each bird-winter, (2) departure date from the wintering grounds for each bird-winter, (3) average areal extent of each wintering site, and (4) average distance between wintering sites. We used GLMMs in R to examine how the centroid latitude of individual wintering sites affected the arrival and departure to the corresponding wintering site and how year affected the arrival and departure dates to and from the wintering grounds. We used a Gaussian error distribution for the models analyzing arrival and departure dates and a Gamma error distribution with a log link function for analyzing wintering site area and distance between wintering sites. We chose to use the Gamma error distribution for the wintering site area and distance between wintering sites because the response variables were continuous and positive, yet contained values near 0 , limiting the application of the Gaussian distribution. Arrival and departure dates did not have values near 0 .

To better understand if movement metrics differed along a latitudinal gradient, we averaged the latitude of all telemetry points per bird per wintering season to find the mean latitude of each bird for each wintering season ("mean wintering latitude" from here on). We used the mean wintering latitude as a metric to indicate where birds spent the majority of their time along the Atlantic Coast. For example, birds that winter along the coast of New England had a higher mean wintering latitude than birds that spent most of the winter off the coast of the Carolinas. We calculated the standard deviation of the latitude per bird per wintering season to capture movement variation for each bird. To test if birds at lower latitudes had higher standard deviations of movement, we estimated the correlation between variation in latitude and mean wintering latitude and found that they were highly correlated $(\mathrm{R}=-0.821)$. To avoid multicollinear variables in the models, we chose to only use the mean wintering latitude variable for our models.

\section{Habitat use of wintering sites by latitude}

We examined the habitat features of wintering sites based on latitude at the centroid of the wintering site. We used GLMM with a normal distribution with year and individual scoter as random effects to quantify differences of wintering sites in bathymetry, ocean floor slope, distance to shore, and ocean floor substrate. To calculate the value for each covariate of interest for a wintering site, we either used the center of the wintering site (for distance to shore) or calculated the mean of a given variable for each wintering site using the raster package (Hijmans et al. 2017). We chose to not contrast habitat features of wintering sites to nearby available locations for several reasons. First, it was unclear what "available" meant for these birds because they were covering large areas throughout the winter (Jones 2001). Sampling a random point from within a marine ecoregion would by no means indicate that it was "available" to a bird at a given time. Second, our main focus was to highlight how habitat use varied across a geographic gradient. By breaking up each wintering site into a specific marine ecoregion, we would have lost the gradient of sites 
and consolidated considerable geographic differences into two main ecoregions. Last, we already know that for a given distance to shore, the Carolinian Marine Ecoregion has less depth relative to the Virginian Marine Ecoregion because of the continental shelf.

We obtained bathymetric data from the National Oceanic and Atmospheric Administration's (NOAA) National Geophysical Data, ETOPO1 Global Relief Model where depth is based on mean sea level (1 arc-minute; Amante and Eakins 2009). We calculated ocean floor slope by using the bathymetry data (Amante and Eakins 2009) and finding the difference of the values between neighboring cells. We calculated distance to shore by finding the Euclidean distance between the center of the wintering site and the shoreline. We obtained shoreline shapefile from NOAA's National Centers for Environmental Information Global Self-consistent, Hierarchical, High-resolution Geography Database (GSSH), version 2.3.6, using the intermediate resolution (i) and the boundary between land and ocean (L1; Wessel and Smith 1996). We obtained the ocean floor substrate data from NOAA's Office of Coastal Management Digital Coast, Atlantic Seafloor Sediment Continental Margin Mapping (CONMAP; 0.00001 latitude/longitude; Poppe et al. 2014). The substrate types were characterized by sediment grain size. The substrate classification of each polygon was the dominant surface substrate type for that polygon. We standardized variables to a mean value of zero with a standard deviation of 1 .

\section{RESULTS}

\section{Wintering sites}

There were 44 birds that provided data for a least one winter with 18 birds providing data for more than one wintering season (Table 1). Black Scoters used 1.8 (95\% CI: 1.6-2.0) distinct wintering sites on average (one wintering site $\mathrm{n}=25$, two wintering sites $\mathrm{n}$ $=27$, and three wintering sites $n=14$ ). In three winter seasons, Black Scoters' third wintering site was the same as the first wintering site. The mean number of days spent during the first period at a wintering site was $70.8(95 \% \mathrm{CI}$ : $59.4-82.3$, range $=$ $7-167)$. The mean number of days spent during the second period at a winter site was 64.0 (95\% CI: 53.1-75.0, range $=9-119)$. The average number of days spent during the third period at a winter site was 41.4 (95\% CI: 26.4-56.3, range $=7-115)$. In four winter seasons, Black Scoters used three separate wintering sites and used a previous site a second time. The mean number of days spent during the fourth period at a winter site was $27.0(95 \% \mathrm{CI}$ : $8.1-45.8$, range $=14-51$ ). There were 23 instances when a Black Scoter provided data for two consecutive years and 10 of those instances had overlap with the previous year's wintering site. The spatial overlap between wintering seasons averaged $14.7 \%(95 \%$ CI: 7.8-22.1) of the total wintering site area used in the consecutive years.

\section{Arrival and departure dates}

The timing of Black Scoter winter movements in the Atlantic varied greatly among individuals. The average arrival date to the first wintering site on the wintering grounds was 12 November (95\% CI: $\pm 8-16$ November, range $=6$ September -17 December $)$. There was no difference in the arrival date by $\operatorname{sex}(P=0.5211)$ or by mean wintering latitude of the scoter $(P=0.817)$. The arrival date to the first wintering site did differ by site latitude $(P=0.031)$. Black Scoters whose first wintering site was located at higher latitudes (more northern) arrived at their first wintering site earlier than Black Scoters whose first wintering site was at lower latitudes (Fig. 3). The average departure date from the first wintering site was 21 January $(95 \%$ CI \pm 1 January-3 February, range $=11$ October-17 April). The departure date from the first wintering site differed by site latitude $(P=0.041)$. Black Scoters with first wintering sites at higher latitudes departed from their wintering site earlier than those at lower latitudes (Fig. 3). The average date that Black Scoters arrived at their second wintering site was 26 December $(95 \% \mathrm{CI} \pm 15$ December-8 January, range $=25$ October-4 April). The average departure date from their second wintering site was 2 March (95\% CI \pm 18 February-12 March, range $=5$ November -27 April). Arrival date $(P=0.175)$ and departure date $(P=0.110)$ from the second wintering site did not differ by site latitude. The Black Scoters average arrival date to their third wintering site was 5 February $(95 \%$ CI \pm 17 January24 February, range $=29$ November -7 April), and did not differ by site latitude $(P=0.725)$. The average departure date from the third wintering site was 20 March $(95 \%$ CI \pm 9 March-1 April, range $=29$ January -20 April $)$, and did differ by site latitude $(P=$ 0.005). Black Scoters whose third wintering sites were at lower latitudes departed from the third wintering site earlier than scoters whose third wintering sites were at higher latitudes. The average date that Black Scoters arrived at their fourth wintering site was 23 February $(95 \%$ CI \pm 6 February-12 March, range $=1$ February-11 March). The average departure date from the fourth wintering site was 18 March $(95 \%$ CI \pm 9-27 March, range = 5$25 \mathrm{March})$. The average departure date from the final wintering site was 25 March (95\% CI: $\pm 22-28$ March, range = 22 January27 April). Departure date for males was an average nine days earlier than females $(P=0.001)$. Departure date from the last wintering site did not differ by mean wintering latitude of the scoter $(P=0.367)$. Departure date from the last wintering site differed by site latitude $(P=0.004)$ with scoters at a lower latitude departing earlier than scoters at higher latitude.

Table 1. The number of satellite tagged Black Scoters (Melanitta americana) to study wintering along the Atlantic coast of the United States from 2009/2010 to 2012/2013. Columns indicate the number of Black Scoters included in the analysis by year, sex, and the number of individuals used in multiple years ("previous year total" and number of "(female)").

\begin{tabular}{lcccc}
\hline \hline Winter Year & Female & Male & Total & $\begin{array}{c}\text { Previous } \\
\text { Year Total } \\
\text { (Female) }\end{array}$ \\
\hline $2009-2010$ & 14 & 0 & 14 & $0(0)$ \\
$2010-2011$ & 13 & 15 & 28 & $0(0)$ \\
$2011-2012$ & 8 & 10 & 18 & $17(7)$ \\
$2012-2013$ & 3 & 3 & 6 & $6(3)$ \\
Total & 38 & 28 & 66 & $23(10)$ \\
\hline
\end{tabular}

\section{Distance between wintering sites}

The average distance between wintering sites was greatest between the second period of time at a wintering site and the third period of time at a wintering site (Table 2). Black Scoters primarily traveled south from the first wintering site to the second wintering 
Fig. 3. Arrival (top row) and departure (bottom row) dates with $95 \%$ confidence intervals for Black Scoters (Melanitta americana) during the wintering seasons of 2009-2013 along the Atlantic coast of the United States. Each column represents dates at each wintering site (1-4 sites) by the centroid latitude of that wintering site.
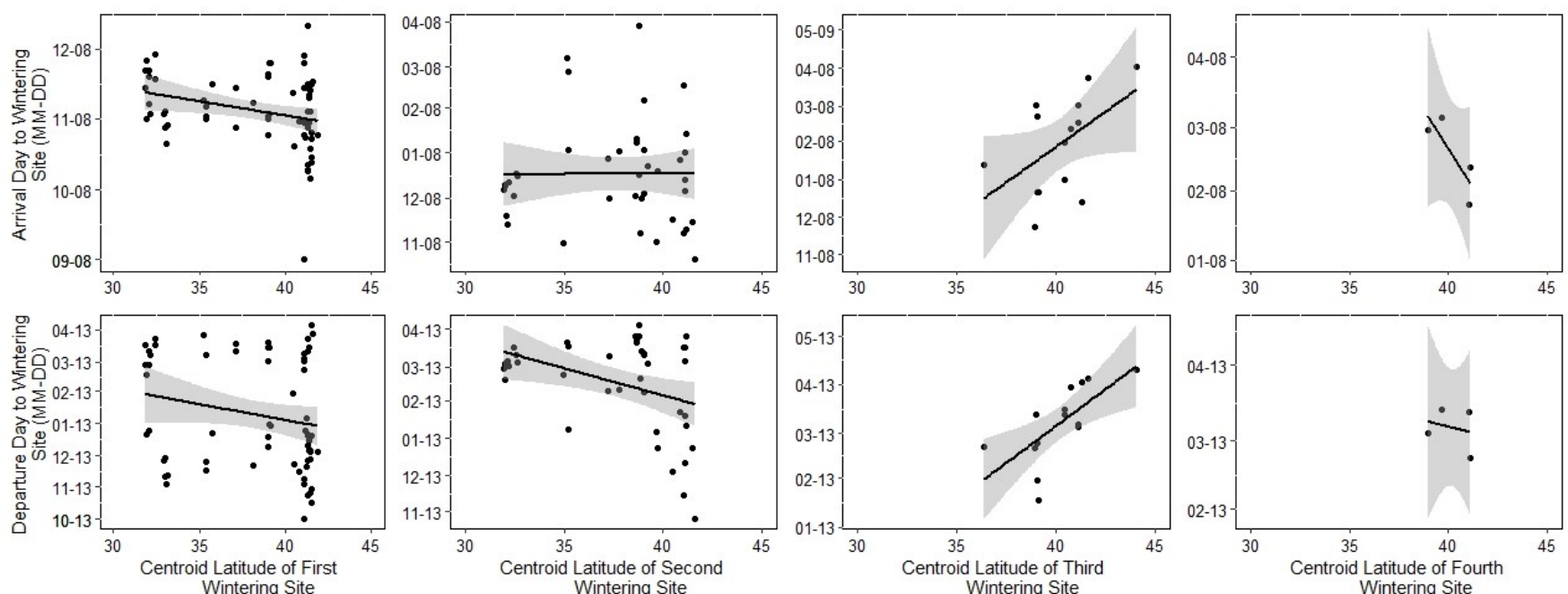

site $(78 \%$ of birds, $\mathrm{n}=41)$ and north for subsequent movements between wintering sites $(57 \%$ of birds, $n=14$ from second to third wintering sites and $100 \%$ of birds, $n=4$ from third to fourth wintering sites; Table 2). There was no difference in the average distance between wintering sites between sexes $(P=0.217)$. The average distance between wintering sites increased as mean wintering latitude decreased $(P=0.015)$.

Table 2. Distances (in $\mathrm{km}$ ) between wintering sites for Black Scoters (Melanitta americana) wintering along the Atlantic coast of the United States from 2009/2010 to 2012/2013. Direction of movement indicates the cardinal direction the majority of birds moved between sites.

\begin{tabular}{|c|c|c|c|c|c|c|}
\hline $\begin{array}{l}\text { Wintering } \\
\text { Site }\end{array}$ & $\mathrm{n}$ & $\begin{array}{c}\text { Mean } \\
\text { Distance } \\
(\mathrm{km})\end{array}$ & $\begin{array}{c}\text { Lower } \\
95 \% \mathrm{CI} \\
(\mathrm{km})\end{array}$ & $\begin{array}{c}\text { Upper } \\
95 \% \text { CI } \\
(\mathrm{km})\end{array}$ & Range (km) & $\begin{array}{l}\text { Direction } \\
\text { of } \\
\text { movement }\end{array}$ \\
\hline $1^{\text {st }}-2^{\text {nd }}$ & 41 & 350 & 260 & 440 & $40-1240$ & South \\
\hline $2^{\text {nd }}-3^{\text {rd }}$ & 14 & 440 & 220 & 660 & $40-1410$ & North \\
\hline $3^{\text {rd }}-4^{\text {th }}$ & 4 & 350 & 330 & 380 & $320-390$ & North \\
\hline
\end{tabular}

\section{Wintering site area}

The average size of the first wintering site was $2710 \mathrm{~km}^{2}(95 \% \mathrm{CI}$ : $1930-3500, \mathrm{n}=66)$, range $=30-12,300)$. The average size of the second wintering site was $3220 \mathrm{~km}^{2}(95 \% \mathrm{CI}: 2140-4300, \mathrm{n}=41)$, and third wintering site was $2030 \mathrm{~km}^{2}$ (95\% CI: 1190-2870, $\mathrm{n}=$ 14). There was no difference in the average wintering site area between the sexes $(P=0.570)$. The average wintering site area increased as mean wintering latitude decreased $(P=0.024)$.

\section{Habitat use of wintering sites by latitude}

The variables bathymetry, distance to shore, and ocean floor slope differed significantly between the wintering sites centroid latitude (Fig. 4). Higher latitude wintering sites were negatively associated with depth (occurred in deeper waters; $\beta=-1.652,95 \% \mathrm{CI}:-2.393$ $-0.910, P<0.001$ ) and shore (occurred closer to shore; $\beta=-1.132$, 95\% CI: $-1.623--0.640, P<0.001)$ and positively associated with slope (occurred on steeper slopes; $\beta=1.130,95 \%$ CI: $0.518-1.741$, $P<0.001)$ compared to the southern wintering sites. None of the different types of substrates were found to be significant.

\section{DISCUSSION}

Winter movement of Black Scoters in the Atlantic varies greatly among individuals and latitude. The results of our study indicate that most Black Scoters arrived and departed from the wintering grounds within a two-week period. Moreover, our results suggest that there are differences in the movement patterns and wintering ecology of Black Scoters that vary with latitude along the Atlantic Coast of the United States.

There was no difference found between sex and arrival date to the first wintering site, average wintering site area, and average distance between wintering sites, although, the lack of differentiation between male and female arrival date has been reported in other sea ducks (Merkel et al. 2006, Oppel et al. 2008, Loring et al. 2014). Our results for arrival date may be confounded with transmitter deployment because it is unlikely that females implanted with satellite transmitters in the spring bred that year, as an effect from implanting the transmitter, so females may have begun their southern migration earlier than if they were successful breeders (Oppel et al. 2008, Fast et al. 2011, Bentzen and Powell 2015). Males did have an earlier departure date from the wintering grounds than females. Many species of ducks form pairs in the spring and males may depart earlier than females to the spring staging area to maximize the possibility of forming a pair bond (Rohwer and Anderson 1988). Females may also remain longer on wintering or migration grounds to acquire additional reserves for breeding. Overall, except for departure date from the wintering grounds, there was no statistical difference between male and female Black Scoters in their ecology and movement on their 
Fig. 4. (A) Mean bathymetry (m), (B) distance to shore (m), and (C) ocean floor slope (degrees), with $95 \%$ confidence interval by latitude of the centroid of wintering sites for Black Scoter (Melanitta americana) along the Atlantic Coast of the United States from September 2009 to April 2013.
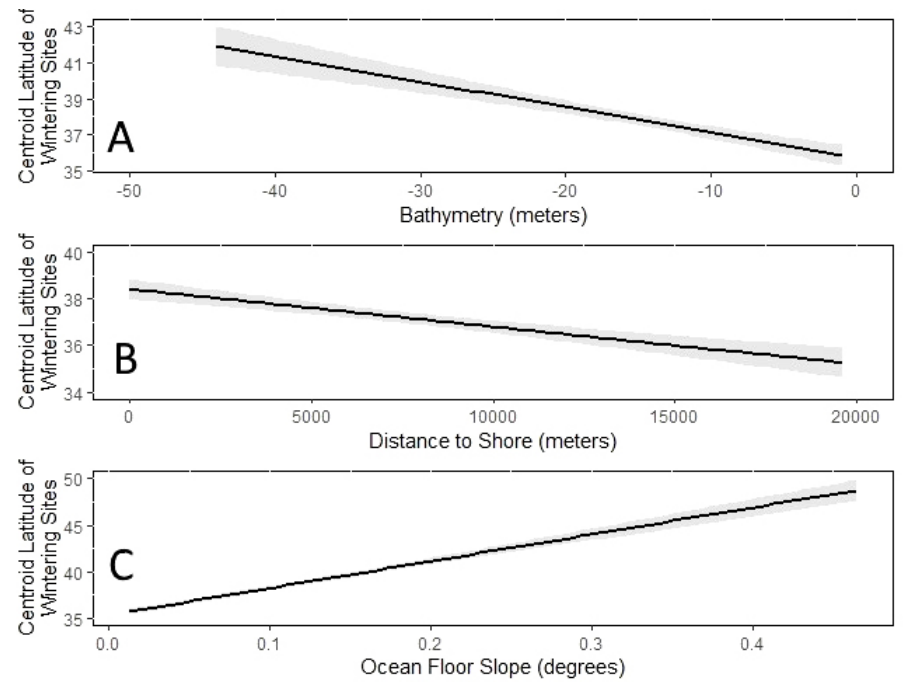

Erratum: Figure 4 in the original publication was incorrect. This correct version of Figure 4 was put into place on 18 Feb. 2022.

wintering grounds on the Atlantic coast. As with timing of wintering movements, wintering range of Black Scoters did not vary by sex. King Eiders (Somateria spectabilis; Oppel et al. 2008), Steller's Eiders (Polysticta stelleri), and Harlequin Ducks (Histrionicus histrionicus; Reed and Flint 2007) similarly do not differ in the size of the wintering range based on sex. Males and females may not have had different wintering movements because they are similar in size, have comparable energetic costs, and winter in mixed-sex flocks (Bordage and Savard 2011). Additionally, a lack of differences may be because males and females largely overlap in wintering locations and have similar foraging behaviors (Lewis et al. 2008). Although, in other regions or time periods, some sex related foraging differences have been found (Bengtson 1971, Tschaekofske 2010).

Although Black Scoters generally did not exhibit differences in winter movement ecology in relation to sex, there were several differences in movement that varied by latitude. Black Scoters that wintered at a lower mean wintering latitude, i.e., that spent a higher portion of the winter along the southern coast, traveled about twice as far between wintering sites than scoters that had a higher mean wintering latitude, i.e., spent most of the winter along the northern coast. This may be because Black Scoters are less restrictive in their habitat requirements than other sea ducks such as the Common (Somateria mollissima) and Spectacled Eiders (Somateria fischeri), during winter and are able to move away from areas with less ideal conditions, such as poor prey availability (Phillips et al. 2006, Žydelis and Richman 2015). Black Scoters wintering at a lower mean latitude had more than double the average wintering site area than scoters wintering at a higher mean latitude. The concentration of resources could vary along the Atlantic coast resulting in the disparity of size of wintering site areas in different regions. An increase of prey variability and higher rates of prey depletion have been associated with greater distances between wintering sites (Vaitkus and Bubinas 2001, Kirk et al. 2007) and larger home ranges (De La Cruz et al. 2014).
The wintering sites used by Black Scoters varied by water depth, ocean floor slope, and distance to shore based on their latitude. Removing nonavailable habitat such as land may have affected some calculations of the site centroid, but is unlikely to have caused large changes as Black Scoters rarely use land during winter. Wintering sites with a higher centroid latitude (northern) were in deeper waters, closer to shore, and on steeper slopes compared to the wintering sites with a lower centroid latitude. Bivalves occur in shallower water along the southeastern coast than in New England (Kaiser et al. 2006), so although Black Scoters can dive to depths exceeding $20 \mathrm{~m}$ (Nilsson 1972), they might occur in shallower water depths along the southeastern coast because of higher bivalve densities. Thus, Black Scoters may use shallower waters along the southeastern coast because bathymetry may be a surrogate for bivalve distribution along the Atlantic coast of the United States (Barry and Dayton 1991, Kaiser et al. 2006).

Wintering sites with a lower centroid latitude (southern) were located further from shore than wintering sites with a higher centroid latitude. Local topography could explain differences in wintering sites across latitudes. Water depth along the higher latitudes of the Atlantic coast, in areas such as New England, increases quickly over a relatively short distance, whereas the water depth increases slowly over a relatively long distance along the lower latitude of the Atlantic coast. The rapid increase in water depth at higher latitudes limits the area accessible to Black Scoters for diving and foraging in contrast to the flat topography located on the South Atlantic Bight at the lower latitudes enabling the scoters to use areas further away from shore (Zipkin et al. 2010, Silverman et al. 2013). Black Scoters may be trading off more favorable foraging conditions in more southern latitudes with migration costs to reach those sites.

Prey availability and substrate may also explain Black Scoter associations with ocean floor slope. The average ocean floor slope 
for wintering sites at higher latitudes were steeper than those at lower latitudes. In the southern portion of their wintering range, Black Scoters prefer the flat topography predominantly found on the South Atlantic Bight (Zipkin et al. 2010, Silverman et al. 2013). The flatter topography located primarily at lower latitudes may result in larger areas with available prey accessible to foraging Black Scoters. At higher latitude sites, Black Scoters concentrate over areas with sandy substrates that are primarily found on flatter topography (Stott and Olson 1973, Loring et al. 2013) suggesting that substrate may serve as a surrogate for their preferred prey (Goudie and Ankney 1988).

Habitat features associated with different benthic prey types and densities can greatly influence the movement and distribution of diving ducks, such as sea ducks (Nilsson 1972, Stott and Olson 1973, Kirk et al. 2008, Schummer et al. 2008). Black Scoters that wintered at higher latitudes traveled on average half the distance than Black Scoters wintering at lower latitudes (Loring et al. 2014), suggesting that food resources are more concentrated at higher latitudes and become less concentrated as the latitude decreases. Black Scoters might travel further along the coast of the United States because resources, such as food, could be less concentrated because of variation in habitat features, resulting in scoters moving further distances to find resources (Kirk et al. 2007, 2008). The concentration of resources may increase distance between wintering sites and the area of wintering sites as well (Kirk et al. 2008).

Our study, like several other recent sea duck studies (e.g., Loring et al. 2014, Meattey et al. 2019, Lamb et al. 2020), used tagged individuals over multiple seasons. Individuals included in our study overlapped with previous wintering sites approximately $15 \%$. Compared to sites along the northeastern Atlantic Coast of the United States, overlap with previous wintering sites was similar to Black Scoters (Loring et al. 2014) and less than Whitewinged Scoters (Melanitta deglandi; Meattey et al. 2019). A limitation of our study is that individuals may show tendencies to winter at similar latitudes in each year. Overlap of wintering sites may also vary depending on how "site" is defined.

Understanding wildlife population distributions and dynamics as they relate to habitat selection allows for more effective conservation planning, minimizing human conflicts, and better survey planning for future monitoring programs (Newbold and Eadie 2004, Rushing et al. 2017). Our study provides insight on wintering ecology and movement of Black Scoters along the Atlantic coast of the United States. Habitat use of wintering sites for Black Scoters does vary geographically along a latitudinal gradient. Abiotic conditions encountered on the wintering grounds may be important to Black Scoter population dynamics through the indirect effects of dispersal decisions, spring migration, and reproductive success (Scott 1998, Martin and Wiebe 2004). Information about geographic variation in wintering site selection and movements, coupled with other studies on Black Scoter wintering ecology, allows for more effective conservation and management of this species, while minimizing human conflicts.

Although habitat use and movement did not differ between male and female Black Scoters, wintering sites located at higher latitudes along the coast of the United States were smaller and closer to shore than wintering sites located at lower latitudes along the coast of the United States. If protection of wintering habitat Black Scoters along the Atlantic coast of the United States is needed, then management efforts would benefit from accounting for spatial variation in habitat along the latitudinal gradient of the Black Scoter wintering range. High-quality Black Scoter habitat in New England may not be the same habitat used by Black Scoters wintering further south. Wintering sites located at southern latitudes along the coast of the United States were larger and were further apart than wintering sites located at more northern latitudes, indicating that larger areas of habitat may be needed over a broader extent in the southeast. Additionally, our results provide key information about dates and movement ecology for focusing surveying efforts for Black Scoter abundance and distribution along the Atlantic coast. Because of the widespread movements of Black Scoters, one-time censuses will probably underestimate the population of Black Scoters using an area during the wintering period. This possible bias should be considered when assessing anthropogenic activities and structures (West and Caldow 2006), such as wind turbines for offshore energy.

Responses to this article can be read online at: https://www.ace-eco.org/issues/responses.php/1654

\section{Acknowledgments:}

Salary for H.M.P. was provided through U.S. Geological Survey and the Department of Forestry and Environmental Conservation at Clemson University. Funding for deployments of the radios was provided by the SDJV, the USFWS, and Environment and Climate Change Canada. For assistance in deployments of radios we thank the following: USFWS: Tim Bowman; ECCC: Keith McAloney, Andrew Hicks, Jean-Pierre Savard, and Sean Boyd; USGS: Matthew Perry and Glenn Olsen; NB-ERD: Kevin Connor, Todd Byers, Roger Selesse, and Luc Gagnon; Avian Specialty Veterinarian Services: Scott Ford; RI-DEM: Jason Osenkowski; and University of Rhode Island: Scott McWilliams. We thank C. Jachowski, P. Jodice, R. Kaminski, and A. Powell for feedback on earlier versions of this manuscript. Any use of trade, firm, or product names is for descriptive purposes only and does not imply endorsement by the U.S. Government.

\section{LITERATURE CITED}

Alisauskas, R. T., and C. D. Ankney. 1992. The cost of egg laying and its relationship to nutrient reserves in waterfowl. Pages 30-61 in B. D. J. Batt, A. D. Afton, M. G. Anderson, C. D. Ankney, D. H. Johnson, J. A. Kadlec, and G. L. Krapu, editors. Ecology and management of breeding waterfowl. University of Minnesota Press, Minneapolis, Minnesota, USA.

Alisauskas, R. T., and J.-M. Devink. 2015. Breeding costs, nutrient reserves, and cross-seasonal effects: dealing with deficits in sea ducks. Pages 125-168 in J.-P. L. Savard, D. V. Derksen, D. Esler, and J. M. Eadie, editors. Ecology and conservation of North 
American sea ducks. Studies in Avian Biology (no. 46). CRC Press, Boca Raton, Florida, USA. https://doi.org/10.1201/ b18406-11

Amante, C., and B. W. Eakins. 2009. ETOPO1 1 Arc-minute global relief model: procedures, data sources and analysis. National Geophysical Data Center, NESDIS, NOAA, U.S. Department of Commerce, Boulder, Colorado, USA.

Barry, J. P., and P. K. Dayton. 1991. Physical heterogeneity and the organization of marine communities. Pages 270-320 in J. Kolasa, and S. T. A. Pickett, editors. Ecological heterogeneity. Springer-Verlag, New York, New York, USA. https://doi. org/10.1007/978-1-4612-3062-5_14

Bates, D., M. Mächler, B. Bolker, and S. Walker. 2015. Fitting linear mixed-effects models using lme4. Journal of Statistical Software 67:1-48. https://doi.org/10.18637/jss.v067.i01

Bengtson, S.-A. 1971. Food and feeding of diving ducks breeding at Lake Mývatn, Iceland. Ornis Fennica 48:77-92.

Bentzen, R. L., and A. N. Powell. 2015. Dispersal, movements and site fidelity of post-fledging King Eiders Somateria spectabilis and their attendant females. Ibis 157:133-146. https:// doi.org/10.1111/ibi.12217

Beuth, J. M., S. R. Mcwilliams, P. W. C. Paton, and J. E. Osenkowski. 2017. Habitat use and movements of Common Eiders wintering in southern New England. Journal of Wildlife Management 81:1276-1286. https://doi.org/10.1002/jwmg.21289

BirdLife International. 2013. Black Scoter: Melanitta americana. The IUCN Red List of Threatened Species. https:// doi.org/10.2305/iucn.uk.2013-2.rlts.t22732425a50444299.en

Bordage, D., and J.-P. L. Savard. 2011. Black Scoter (Melanitta americana), version 2.0. In A. F. Poole, editor. The birds of North America. Cornell Lab of Ornithology, Ithaca, New York, USA. https://doi.org/10.2173/bna.177

Bowman, T. D., E. D. Silverman, S. G. Gilliland, and J. B. Leirness. 2015. Status and trends of North American sea ducks: reinforcing the need for better monitoring. Pages 1-28 in J.-P. L. Savard, D. V. Derksen, D. Esler, J. M. Eadie, editors. Ecology and conservation of North American sea ducks. Studies of Avian Biology (no. 46), CRC Press, Boca Raton, Florida, USA. https:// doi.org/10.1201/b18406-7

Boyd, W. S., T. D. Bowman, J.-P. L. Savard, and R. D. Dickson. 2015. Conservation of North American sea ducks. Pages 529-559 in J.-P. Savard, D. V. Derksen, D. Esler, and J. M. Eadie, editors. Ecology and conservation of North American sea ducks. Studies in Avian Biology (no. 46), CRC Press, Boca Raton, Florida, USA. https://doi.org/10.1201/b18406-20

Camphuysen, C. J., C. M. Berrevoets, H. J. W. M. Cremers, A. Dekinga, R. Dekker, B. J. Ens, T. M. van der Have, R. K. H. Kats, T. Kuiken, M. F. Leopole, J. van der Meer, and T. Piersma. 2002. Mass mortality of Common Eiders (Somateria mollissima) in the Dutch Wadden Sea, winter 1999/2000: starvation in a commercially exploited wetland of international importance. Biological Conservation 106:303-317. https://doi.org/10.1016/ S0006-3207(01)00256-7
De La Cruz, S. E. W., J. M. Eadie, A. K. Miles, J. Yee, K. A. Sparagens, E. C. Palm, and J. Y. Takekawa. 2014. Resource selection and space use by sea ducks during the non-breeding season: implications for habitat conservation planning in urbanized estuaries. Biological Conservation 169:68-78. https:// doi.org/10.1016/j.biocon.2013.10.021

Douglas, D. C., R. Weinzierl, S. C. Davidson, R. Kays, M. Wikelski, and G. Bohrer. 2012. Moderating Argos location errors in animal tracking data. Methods in Ecology and Evolution 3:999-1007. https://doi.org/10.1111/j.2041-210X.2012.00245.x

Duong, T. 2017. ks: Kernel smoothing. R package version 1.10.7. [online] URL: https://CRAN.R-project.org/package=ks

Ebbinge, B. S., and B. Spaans. 1995. The importance of body reserves accumulated in spring staging areas in the temperate zone for breeding in Dark-bellied Brent Geese Branta $b$. bernicla in the High Arctic. Journal of Avian Biology 26:105-113. https:// doi.org/10.2307/3677058

Esler, D., D. M. Mulcahy, and R. L. Jarvis. 2000. Testing assumptions for unbiased estimation of survival of radiomarked Harlequin Ducks. Journal of Wildlife Management 64:591-598. https://doi.org/10.2307/3803257

ESRI. 2011. ArcGIS Desktop: Release 10. Environmental Systems Research Institute, Redlands, California, USA.

Fast, P. L. F., M. Fast, A. Mosbech, C. Sonne, H. G. Gilchrist, and S. Descamps. 2011. Effects of implanted satellite transmitters on behavior and survival of female Common Eiders. Journal of Wildlife Management 75:1553-1557. https://doi. org/10.1002/jwmg.220

Fretwell, S. D. 1972. Populations in a seasonal environment. Princeton, University Press, Princeton, New Jersey, USA.

Goudie, R. I., and C. D. Ankney 1988. Patterns of habitat use by sea ducks wintering in southeastern Newfoundland. Ornis Scandinavica 19:249-256. https://doi.org/10.2307/3676718

Greenwood, P. J. 1980. Mating systems, philopatry and dispersal in birds and mammals. Animal Behaviour 28:1140-1162. https:// doi.org/10.1016/S0003-3472(80)80103-5

Grzybowski, J. A., D. J. Tazik, and G. D. Schnell. 1994. Regional analysis of Black-capped Vireo breeding habitats. Condor 96:512-544. https://doi.org/10.2307/1369333

Guillemain, M., J. Elmberg, C. Arzel, A. R. Johnson, and G. Simon. 2008. The income-capital breeding dichotomy revisited: late winter body condition is related to breeding success in an income breeder. Ibis 150:172-176. https://doi.org/10.1111/ j.1474-919X.2007.00700.x

Guillemette, M., J. H. Himmelman, C. Barette, and A. Reed. 1993. Habitat selection by Common Eiders in winter and its interaction with flock size. Canadian Journal of Zoology 71:1259-1266. https://doi.org/10.1139/z93-172

Gunnarsson, T. G., J. A. Gill, P. W. Atkinson, G. Gélinaud, P. M. Potts, R. E. Croger, G. A. Gudmundsson, G. F. Appleton, and W. J. Sutherland. 2006. Population-scale drivers of individual arrival times in migratory birds. Journal of Animal Ecology 75:1119-1127. https://doi.org/10.1111/j.1365-2656.2006.01131. $\mathrm{x}$ 
Hijmans, R. J., J. van Etten, J. Cheng, M. Mattiuzzi, M. Sumner, J. A. Greenberg, O. P. Lamigueriro, A. Bevan, E. B. Racine, A. Shortridge, and A. Ghosh. 2017. raster: Geographic data analysis and modeling. $\mathrm{R}$ package version 2.6-7. [online] URL: https:// CRAN.R-project.org/package $=$ raster

Jodice, P., J. Tavano, and W. Mackin. 2013. Chapter 8: Marine and coastal birds and bats. Pages 475-602 in J. Michel, editor. South Atlantic information resources: data search and literature synthesis. U.S. Department of the Interior, Bureau of Ocean Energy Management, Regulation, and Enforcement, Gulf of Mexico OCS Region, New Orleans, Lousiana, USA.

Jones, J. 2001. Habitat selection studies in avian ecology: a critical review. Auk 118:557-562. https://doi.org/10.1093/auk/118.2.557

Kaiser, M. J., M. Galanidi, D. A. Showler, A. J. Elliott, R. W. G. Caldow, E. I. S. Rees, R. A. Stillman, and W. J. Sutherland. 2006. Distribution and behaviour of Common Scoter Melanitta nigra relative to prey resources and environmental parameters. Ibis 148:110-128. https://doi.org/10.1111/j.1474-919X.2006.00517.x

Kaplan, B., editor. 2011. Literature synthesis for the north and central Atlantic Ocean. OCS Study BOEMRE 2011-012. U.S. Department of the Interior, Bureau of Ocean Energy Management, Regulation and Enforcement, Gulf of Mexico OCS Region, New Orleans, Louisiana, USA.

Kirk, M., D. Esler, and W. S. Boyd. 2007. Morphology and density of mussels on natural and aquaculture structure habitats: implications for sea duck predators. Marine Ecology Progress Series 346:179-187. https://doi.org/10.3354/meps07046

Kirk, M., D. Esler, S. A. Iverson, and W. S. Boyd. 2008. Movements of wintering Surf Scoters: predator responses to different prey landscapes. Oecologia 155:859-867. https://doi. org/10.1007/s00442-007-0947-0

Korschgen, C. E., K. P. Kenow, A. Genron-Fitzpatrick, W. L. Green, and F. J. Dein. 1996. Implanting intra-abdominal radio transmitters with external whip antenna in ducks. Journal Wildlife Management 60:132-137. https://doi.org/10.2307/3802047

Lack, D. 1966. Population studies of birds. Clarendon Press, Oxford, UK.

Lamb, J. S., P. W. C. Paton, J. E. Osenkowski, S. S. Badzinski, A. M. Berlin, T. Bowman, C. Dwyer, L. J. Fara, S. G. Gilliland, K. Kenow, C. Lepage, M. L. Mallory, G. H. Olsen, M. C. Perry, S. A. Petrie, J.-P. L. Savard, L. Savoy, M. Schummer, C. S. Spiegel, and S. R. McWilliams. 2020. Implanted satellite transmitters affect sea duck movement patterns at short and long timescales. Condor, in press. https://doi.org/10.1093/condor/duaa029

Lewis, T. L., D. Esler, and W. S. Boyd. 2008. Foraging behavior of Surf Scoters (Melanitta perspicillata) and White-winged Scoters (M. fusca) in relation to clam density: inferring food availability and habitat quality. Auk 125:149-157. https://doi. org/10.1525/auk.2008.125.1.149

Loring, P. H., P. W. C. Paton, S. R. Mcwilliams, R. A. Mckinney, and C. A. Oviatt. 2013. Densities of wintering scoters in relation to benthic prey assemblages in a North Atlantic estuary. Waterbirds 36:144-155. https://doi.org/10.1675/063.036.0204
Loring, P. H., P. W. C. Paton, J. E. Osenkowski, S. G. Gilliland, J. P. L. Savard, and S. R. Mcwilliams. 2014. Habitat use and selection of Black Scoters in southern New England and siting of offshore wind energy facilities. Journal of Wildlife Management 78:645-656. https://doi.org/10.1002/jwmg.696

Madsen, J., and A. D. Fox. 1995. Impacts of hunting disturbance on waterbirds - a review. Wildlife Biology 1:193-207. https://doi. org/10.2981/wlb.1995.0025

Martin, K., and K. L. Wiebe. 2004. Coping mechanisms of alpine and Arctic breeding birds: extreme weather and limitations to reproductive resilience. Integrative and Comparative Biology 44:177-185. https://doi.org/10.1093/ $\mathrm{icb} / 44.2 .177$

Meattey, D. E., S. R. McWilliams, P. W. C. Paton, C. Lepage, S. G. Gilliland, L. Savoy, G. H. Olsen, and J. E. Osenkowski. 2019. Resource selection and wintering phenology of White-winged Scoters in southern New England: implications for offshore wind energy development. Condor 121(1):duy014. https://doi. org/10.1093/condor/duy014

Merkel, F. R., A. Mosbech, C. Sonne, A. Flagstad, K. Falk, and S. E. Jamieson. 2006. Local movements, home ranges and body condition of Common Eiders Somateria mollissima wintering in southwest Greenland. Ardea 94:639-650.

Newbold, S., and J. M. Eadie. 2004. Using species-habitat models to target conservation: a case study with breeding mallards. Ecological Applications 14:1384-1393. https://doi.org/10.1890/03-5193

Nichols, J. D., K. J. Reinecke, and J. E. Hines. 1983. Factors affecting the distribution of Mallards wintering in the Mississippi Alluvial Valley. Auk 100:932-946. https://doi. org/10.1093/auk/100.4.932

Nilsson, L. 1972. Habitat selection, food choice, and feeding habits of diving ducks in coastal waters of south Sweden during the non-breeding season. Ornis Scandinavica 3:55-78. https:// doi.org/10.2307/3676166

Norris, D. R., P. P. Marra, T. K. Kyser, T. W. Sherry, and L. M. Ratcliffe. 2004. Tropical winter habitat limits reproductive success on the temperate breeding grounds in a migratory bird. Proceedings of the Royal Society B: Biological Sciences 271:59-64. https://doi.org/10.1098/rspb.2003.2569

Oosterhuis, R., and K. Van Dijk. 2002. Food shortage and breeding success in Common Eiders. Atlantic Seabirds 4:29-38.

Oppel, S., A. N. Powell, and D. L. Dickson. 2008. Timing and distance of King Eider migration and winter movements. Condor 110:296-305. https://doi.org/10.1525/cond.2008.8502

Parody, J. M., and T. H. Parker. 2002. Biogeographic variation on nest placement: a case study with conservation implications. Diversity and Distributions 8:11-20. https://doi.org/10.1046/ j.1366-9516.2001.00126.x

Petersen, M. R., and D. C. Douglas. 2004. Winter ecology of Spectacled Eiders: environmental characteristics and population change. Condor 106:79-94. https://doi.org/10.1093/condor/106.1.79 
Phillips, L. M., A. N. Powell, and E. A. Rexstad. 2006. Largescale movements and habitat characteristics of King Eiders throughout the nonbreeding period. Condor 108:887-900. https://doi.org/10.1093/condor/108.4.887

Poppe, L. J., S. J. Williams, and V. F. Paskevich, editors. 2014. USGS east-coast sediment analysis: procedures, database, and GIS data (ver. 3.0). Open-File Report 2005-1001. U.S. Geological Survey, Reston, Virginia. https://doi.org/10.3133/ ofr20051001

R Development Core Team. 2017. R: A language and environment for statistical computing. $\mathrm{R}$ Foundation for Statistical Computing, Austria, Vienna. [online] URL: http://www.Rproject.org/

Rannap, R., A. Lõhmus, and M. Linnamägi. 2012. Geographic variation in habitat requirements of two coexisting newt species in Europe. Acta Zoologica Academiae Scientarum Hungaricae 58:73-90.

Reed, J. A., and P. L. Flint. 2007. Movements and foraging effort of Steller's Eiders and Harlequin Ducks wintering near Dutch Harbor, Alaska. Journal of Field Ornithology 78:124-132. https:// doi.org/10.1111/j.1557-9263.2006.00093.x

Rohwer, F. C., and M. G. Anderson. 1988. Female-biased philopatry, monogamy, and the timing of pair formation in migratory waterfowl. Current Ornithology 5:187-221. https://doi. org/10.1007/978-1-4615-6787-5_4

Rushing, C. S., J. A. Hostetler, T. S. Sillett, P. P. Marra, J. A. Rotenberg, and T. B. Ryder. 2017. Spatial and temporal drivers of avian population dynamics across the annual cycle. Ecology 98:2837-2850. https://doi.org/10.1002/ecy.1967

Schamber, J. L., P. L. Flint, and A. N. Powell. 2010. Patterns of use and distribution of King Eiders and Black Scoters during the annual cycle in northeastern Bristol Bay, Alaska. Marine Biology 157:2169-2176. https://doi.org/10.1007/s00227-010-1481$\mathrm{x}$

Schummer, M. L., S. A. Petrie, and R. C. Bailey. 2008. Interaction between macroinvertebrate abundance and habitat use by diving ducks during winter on northeastern Lake Ontario. Journal of Great Lakes Research 34:54-71. https://doi.org/10.3394/0380-1330 (2008)34[54:IBMAAH]2.0.CO;2

Scott D. A. 1998. Global overview of the conservation of migratory Arctic breeding birds outside the Arctic. Wetland International Publication No. 45. CAFF Technical Report No. 4. Conservation of Arctic Flora and Fauna, Akureyri, Iceland.

Sea Duck Joint Venture. 2015. Atlantic and Great Lakes sea duck migration study: progress report June 2015. Sea Duck Joint Venture, Anchorage, Alaska, USA. [online] URL: http:// seaduckjv.org/science-resources/atlantic-and-great-lakes-sea-duckmigration-study/

Sea Duck Joint Venture Management Board. 2014. Sea duck joint venture strategic plan 2014 - 2018. U.S. Fish and Wildlife Service, Anchorage, Alaska, USA and Canadian Wildlife Service, Sackville, New Brunswick, Canada.

Seaman, D. E., J. J. Millspaugh, B. J. Kernohan, G. C. Brundige, K. J. Raedeke, and R. A. Gitzen. 1999. Effects of sample size on kernel home range estimates. Journal of Wildlife Management 63:739-747. https://doi.org/10.2307/3802664

Sedinger, J. S., and R. T. Alisauskas. 2014. Cross-seasonal effects and the dynamics of waterfowl populations. Wildfowl 4:277-304.

Silverman, E. D., D. T. Saalfeld, J. B. Leirness, and M. D. Koneff. 2013. Wintering sea duck distribution along the Atlantic Coast of the United States. Journal of Fish and Wildlife Management 4:178-198. https://doi.org/10.3996/122012-JFWM-107

Sorensen, M. C., J. M. Hipfner, T. K. Kyser, and D. R. Norris. 2009. Carry-over effects in a Pacific seabird: stable isotope evidence that pre-breeding diet quality influences reproductive success. Journal of Animal Ecology 78:460-467. https://doi. org/10.1111/j.1365-2656.2008.01492.x

Spalding, M. D., H. E. Fox, G. R. Allen, N. Davidson, Z. A. Ferdaña, M. Finlayson, B. S. Halpern, M. A. Jorge, A. Lombana, S. A. Lourie, K. A. Martin, E. McManus, J. Molnar, C. A. Recchia, and J. Robertson. 2007. Marine ecoregions of the world: a bioregionalization of coastal and shelf areas. BioScience 57:573-583. https://doi.org/10.1641/B570707

Stott, R. S., and D. P. Olson. 1973. Food-habitat relationship of sea ducks on the New Hampshire coastline. Ecology 54:996-1007. https://doi.org/10.2307/1935566

Studds, C. E., and P. P. Marra. 2007. Linking fluctuations in rainfall to nonbreeding season performance in a long-distance migratory bird, Setophaga ruticilla. Climate Research 35:115-122. https://doi.org/10.3354/cr00718

Tschaekofske, H. J. 2010. Prey selection and its relationship to habitat and foraging strategy of molting White-winged (Melanitta fusca) and Surf Scoters (M. perspicillata) in Puget Sound, WA, and the Strait of Georgia, BC. Thesis. Evergreen State College, Olympia, Washington, USA.

Vaitkus, G., and A. Bubinas. 2001. Modelling of sea duck spatial distribution in relation to food resources in Lithuanian offshore waters under the gradient of winter climatic conditions. Acta Zoologica Lituanica 11:288-302. https://doi.org/10.1080/13921657.2001 .10512462

Wessel, P., and W. H. F. Smith. 1996. A global, self-consistent, hierarchical, high-resolution shoreline database. Journal of Geophysical Research: Solid Earth 101:8741-8743. https://doi. org/10.1029/96JB00104

West, A. D., and R. W. G. Caldow. 2006. The development and use of individuals-based models to predict the effects of habitat loss and disturbance on wanders and waterfowl. Ibis 148:158-168. https://doi.org/10.1111/j.1474-919X.2006.00520.x

Whittingham, M. J., J. R. Krebs, D. Swetnam, J. A. Vickery, J. D. Wilson, and R. P. Freckleton. 2006. Should conservation strategies consider spatial generality? Farmland birds show regional not national patterns of habitat association. Ecology Letters 10:25-35. https://doi.org/10.1111/j.1461-0248.2006.00992. $\mathrm{x}$

Wilson, S., S. L. Ladeau, A. P. Tøttrup, and P. P. Marra. 2011. Range-wide effects of breeding- and nonbreeding-season 
climate on the abundance of a Neotropical migrant songbird. Ecology 92:1789-1798. https://doi.org/10.1890/10-1757.1

Zipkin, E. F., B. Gardner, A. T. Gilbert, A. F. O'Connell, J. A. Royle, and E. D. Silverman. 2010. Distribution patterns of wintering sea ducks in relation to the North Atlantic Oscillation and local environmental characteristics. Oecologia 163:893-902. https://doi.org/10.1007/s00442-010-1622-4

Žydelis, R., and S. E. Richman. 2015. Foraging behavior, ecology, and energetics of sea ducks. Pages 529-559 in J.-P. Savard, D. V. Derksen, D. Esler, and J. M. Eadie, editors. Ecology and conservation of North American sea ducks. Studies in Avian Biology (no. 46), CRC Press, Boca Raton, Florida, USA. https:// doi.org/10.1201/b18406-13

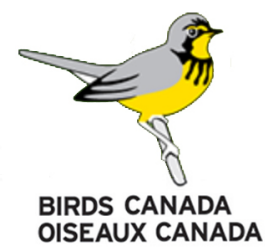

